\section{Empirical Models of Phosphorus Uptake under Different Nitrogen Sources in Dieffenbachia amoena 'Tropic Snow'}

\author{
Silvia Jiménez ${ }^{1}$, Mónica Pérez, Blanca María Plaza, \\ Roberto Salinas, and María Teresa Lao \\ Almeria University, Department of Vegetable Production, Ctra. Sacramento \\ s/n. 04120, Almeriá, Spain
}

Additional index words. phosphorus and water uptake ratio, leaf area index, vapor deficit pressure, global radiation, temperature, water uptake, Dieffenbachia amoena

\begin{abstract}
The study of models for better nutrient uptake estimation can help to improve integrated fertigation management, allowing enhanced water and fertilization use efficiency. The aim of this work was the development of empirical models that permit the prediction of the phosphorus (P) nutritional needs of Dieffenbachia amoena to increase $P$ use efficiency in a recycled system. To achieve this, $P$ uptake was correlated to climate parameters, such as temperature $(T)$, vapor pressure deficit, and global radiation (Rg), and to growth parameters such as leaf area index (LAI). In addition, the influence of the $\mathrm{N}$ form supply $\left(\mathrm{NO}_{3}{ }^{-}-\mathrm{N}\right.$ or $\left.\mathrm{NH}_{4}{ }^{+}-\mathrm{N}\right)$ on $\mathrm{P}$ uptake was studied. The trial was carried out with Dieffenbachia amoena 'Tropic Snow' plants growing in a recycled system with expanded clay as substrate. The crop was placed in an INSOLE buried solar greenhouse, with the plants supplied with equal amounts of $N$, differing in the percentage of the $N$ form applied: $\mathrm{Ta}\left(100 \mathrm{NO}_{3}^{-}: 0 \mathrm{NH}_{4}^{+}\right)$, Tb $\left(50 \mathrm{NO}_{3}^{-}: 50 \mathrm{NH}_{4}^{+}\right)$and $\mathrm{Tc}\left(0 \mathrm{NO}_{3}^{-}: 100 \mathrm{NH}_{4}^{+}\right)$. The $\mathbf{N}$ form applied to Dieffenbachia amoena 'Tropic Snow' plants affects $\mathbf{P}$ and $\mathbf{N}$ uptake, but it does not influence $K$ uptake. Nitrogen and $P$ uptake rates are higher in the plants supplied with $\mathrm{NH}_{4}^{+}$or $\mathrm{NO}_{3}^{-}+\mathrm{NH}_{4}^{+}$than in the plants provided with $\mathrm{NO}_{3}^{-}$alone. The supply of a combination $50 \mathrm{NO}_{3}^{-}: 50 \mathrm{NH}_{4}{ }^{+}$improves $\mathrm{P}$ use efficiency. The study also indicates the possibility of predicting the $P$ uptake rate and $P$ uptake concentration using the proposed models. Phosphorus uptake can be estimated with a model dependent on the $\mathrm{LAI}$ in the $\mathrm{NO}_{3}{ }^{-}-\mathrm{N}$ treatments and on the $\mathrm{LAI}$ and $\mathrm{Rg}$ in the $\mathrm{NH}_{4}{ }^{+}-\mathrm{N}$ treatments. The $\mathrm{P}$ uptake concentration can be calculated with the $P$ uptake, estimated through the previous model, and the experimental water uptake. This parameter would permit the nutritive solutions design, decreasing nutrient losses in open systems.
\end{abstract}

Nowadays, $\mathrm{pH}$ and electrical conductivity (EC) constitute the base fertigation management in soil and soilless greenhouse crops (Jiménez et al., 2005). Changes in the EC and in the composition of the recycled solution result from differences between water and ion uptake, as well as from variations in the nutrient solution concentration (Pardossi et al., 2004). It is difficult to maintain the nutrient balance, because plant uptake can vary among different plant species (Ehret et al., 2005). Adjusting fertility programs according to peak demand periods, production, and environmental conditions will help to prevent periodic nutrient disorders during the crop cycle, and may reduce fertilization costs (Hamlin and Mills, 2001). In recycling systems, it is especially important to find stationary situations in which the accumulation or depletion of an ion does not happen. The recycled solution, because of variations in the nutritive solution, may cause nutrient

Received for publication 2 July 2006. Accepted for publication 5 Dec. 2006.

${ }^{1}$ To whom reprint requests should be addressed; e-mail sbecker@ual.es and Lao, 2005). Some models for the estimation $\mathrm{P}$ uptake have been developed. The general models that study the $\mathrm{P}$ dynamic in the soil, including plant uptake, are ANIMO, GLEAMS, DAYCENT, and MACRO (Lewis and McGechan, 2002); models based on the average plant phenology, like DYFERT (Battilani, 2003); models based on the root architecture (Yan et al., 2001); models that make use of Michaelis-Menten kinetics (Kelly and Kelly, 2001); and others depending on the environmental conditions that allow the estimation of macronutrient uptake (Le Bot et al., 1998). Pardossi et al. (2004) presented empirical models to predict macronutrient uptake of melon plants. The independent variables considered by the model were global radiation ( $\mathrm{Rg}$ ) and air temperature in the greenhouse, crop age and water uptake, as well as a guide ion. Brun and Chazelle (1996) described the $\left(\mathrm{NO}_{3}{ }^{-}-\mathrm{N}\right)$ uptake kinetic on roses with a multiple regression, using agroclimatic factors. Another model was proposed by Kläring et al. (1997), who described the nutrientto-water uptake ratio as a function of environmental conditions by means of models for photosynthesis and transpiration. Papadopoulos and Liburdi (1989) used light, relative humidity, fruit load, and crop age to adjust the base values of nutrient supply for tomato plants in their models.

The use of different nitrogen $(\mathrm{N})$ forms $\left(\mathrm{NH}_{4}{ }^{+}-\mathrm{N}\right.$ or $\left.\mathrm{NO}_{3}{ }^{-}-\mathrm{N}\right)$ shows benefits and limitations. For example, one of the advantages of $\left(\mathrm{NH}_{4}{ }^{+}-\mathrm{N}\right)$ is that it is fixed to the soil or substrate particles thanks to the cation exchange capacity of these materials and, therefore, it is not leached, decreasing $\left(\mathrm{NO}_{3}{ }^{-} \mathrm{N}\right)$ pollution (Jiménez et al., 2005). Most plants can use both $\mathrm{N}$ forms, but the use efficiency and the preference for each form depend on the species, variety, plant age (Abbès et al., 1995), nutritional conditions (pH and others), environmental conditions, percentage of the two $\mathrm{N}$ forms, and concentration of other nutrients (Mengel and Kirkby, 2001). The $\mathrm{N}$ form can also have an effect on leaf mineral composition and nutrient uptake (Bar-Tal et al., 2001), modifying fertilizer use efficiency (Jiménez and Lao, 2005). Generally, P uptake and $P$ leaf concentration increase when $\mathrm{NH}_{4}{ }^{+}-\mathrm{N}$ is replaced by $\mathrm{NO}_{3}{ }^{-} \mathrm{N}$ (Abbès et al., 1995), as well as in soil culture (Thomson et al. 1993).

The aim of this work is the development of empirical models that permit the prediction of the P nutritional needs of Dieffenbachia amoena to increase $\mathrm{P}$ use efficiency in a recycled system, although this model can also be applied in principle to other plant species. To achieve this, $\mathrm{P}$ uptake has been correlated to climate parameters, such as temperature, vapor pressure deficit (VPD), and $\mathrm{Rg}$, and to growth parameters such as leaf area index (LAI). In addition, the influence of the $\mathrm{N}$ form supply $\left(\mathrm{NO}_{3}{ }^{-} \mathrm{N}\right.$ or $\left.\mathrm{NH}_{4}{ }^{+} \mathrm{N}\right)$ on $\mathrm{P}$ uptake and on the defined as the ratio of $\mathrm{P}$ and water uptake, have been studied. The last parameter will be useful to control the nutrient solution concentration. 


\section{Materials and Methods}

Plant growth environment and irrigation systems. The trial was carried out in an INSOLE buried solar greenhouse, as described by Lao et al. (2003), $150 \mathrm{~m}^{2}$, with zenithal ventilation, with relative humidity and temperature control equipment. Being buried, this type of greenhouse allows one to maintain the best climatic conditions for this crop (Lao et al., 2003).

The variety studied was $D$. amoena 'Tropic Snow'. The plant density was 3.2 plant $/ \mathrm{m}^{2}$. Single plants were grown in a 17-cm-diameter pot, and the substrate used was expanded clay $(3-8 \mathrm{~mm})$. Two trials were conducted. The first trial was conducted from 10 Nov. to 9 June 2001, $200 \mathrm{~d}$ after transplanting, and the second trial was carried out from 19 Dec. to 13 Aug. 2002, $240 \mathrm{~d}$ after transplanting. During both trials, the crops were in a vegetative phenological state.

A recycled fertigation system was used. The fertilizer was applied through drip irrigation, with one emitter per plant, with a flow rate of $2 \mathrm{~L} \cdot \mathrm{h}^{-1} /$ emitter. Each irrigation lasted $1 \mathrm{~min} 15 \mathrm{~s}$, and the timing was one irrigation every $10 \mathrm{~min}$.

Nutritional treatments. There were three treatments tested that differed in the percentage of the $\mathrm{N}$ form applied: Ta $\left(100 \mathrm{NO}_{3}{ }^{-}\right.$: $\left.0 \mathrm{NH}_{4}^{+}\right)$, $\mathrm{Tb}\left(50 \mathrm{NO}_{3}^{-}: 50 \mathrm{NH}_{4}^{+}\right)$, and $\mathrm{Tc}$ $\left(0 \mathrm{NO}_{3}{ }^{-}: 100 \mathrm{NH}_{4}{ }^{+}\right)$. The nutrient solutions used are listed in Table 1.

The recycled solution was renewed every $20 \mathrm{~d}$ to adjust the nutrient concentration to the initial values. The concentration of $\mathrm{NO}_{3}{ }^{-}$, $\mathrm{NH}_{4}{ }^{+}$, and $\mathrm{H}_{2} \mathrm{PO}_{4}^{-}$was analyzed by spectrophotometry (Ministry of Agriculture and Fishing, 1994).

Sampling. Climatic parameters were monitored by means of a climate computer (LCC 900 VOLMATIC). External radiation was measured every 15 min with a Q20-B sensor, whereas temperature and humidity were recorded with RTV-5B sounds. To estimate internal radiation, the cover transmission coefficient was estimated fortnightly as a ratio between internal and external radiation, measured with a manual quantum photoradiometer (Delta OHM, model RAD/ PAR, Disca, Vicar). A shade screen was used during the summer season.

The VPD was estimated using the equation proposed by Rosenberg et al. (1983): $\mathrm{VPD}=\mathrm{e}_{\mathrm{s}}-\mathrm{e}_{\mathrm{a}}, \mathrm{e}_{\mathrm{s}}=0.61078 \mathrm{e}^{[(17.269 \mathrm{~T}) /(\mathrm{T}+237.30)]}$ and $\mathrm{e}_{\mathrm{a}}=\left(\mathrm{RHxe}_{\mathrm{s}}\right) / 100$, where $\mathrm{e}_{\mathrm{s}}$ is the saturated vapor pressure, $e_{a}$ is the actual vapor pressure measured in kilopascals $(\mathrm{kPa}), \mathrm{T}$ is the temperature in degrees Celsius, and $\mathrm{RH}$ is the relative humidity measured as a percentage.

Leaf area was estimated by a nondestructive method using the formula

$$
\mathrm{S}=\mathrm{k} \times \mathrm{L} \times \mathrm{A}
$$

where $\mathrm{S}$ measured in square centimeters is the foliar area, $\mathrm{k}$ is a constant, $\mathrm{L}$ is the leaf length in centimeters, and A is the leaf width in centimeters. The coefficient $\mathrm{k}$ is specific for each species and was estimated experimentally by the regression analysis of 50 leaves of different size, being the leaf area measured with a Delta-T (Disca, Vicar) area meter. Leaf area index (measured in square meter per square meter) was estimated as the leaf area per plantation framework.

Water uptake. The water uptake was estimated as the difference between the initial and the final volumes in a transparent tube previously calibrated and fixed to the nutritive solution tank. The measurements correspond to an interval of $20 \mathrm{~d}$.

Estimation of phosphorus uptake and phosphorus uptake concentration. Net uptake was measured each $20 \mathrm{~d}$ as the difference between the initial and the final ion concentrations of the nutrient solution, as proposed by Le Bot et al. (1998), and it was expressed mathematically as

$$
A_{s}=\left(C_{i} H_{i}-C_{f} H_{f}\right)(N 20)^{-1}
$$

where $A_{s}$ is the uptake measured in millimolecules per day per plant, $C_{i}$ and $C_{f}$ are the initial and final $\mathrm{P}$ concentrations during the period measured in millimolecules per liter, $\mathrm{H}_{\mathrm{i}}$ and $\mathrm{H}_{\mathrm{f}}$ are the initial and final nutrient solution volumes during the estimated period respectively, $\mathrm{N}$ is the number of days of the period, and 20 is the number of plants that constituted each replication. The $\mathrm{P}$ uptake concentration (measured in millimolecules per liter) can be defined as P uptake (measured in millimolecules per day per plant) per unit of water uptake (measured in liters per day per plant).

Experimental design and statistical analysis. The experimental design was unifactorial ( $\mathrm{N}$ form), with three treatments, three replications per treatment, and 20 plants per replication, during the two crop cycles. Data analysis was conducted using the software packages Excel 7.0 and Statgraphics plus 4.0 (Ruano informática, S.L., Almeria). Analysis of variance and LSD $(P<0.05)$ were undertaken to compare $\mathrm{P}$ uptake between treatments. Simple regressions between $\mathrm{P}$ uptake concentration and $\mathrm{P}$ uptake related to climatic and growth parameters were made to generate models. From all parameters considered, the one with a higher determina- tion coefficient $\left(R^{2}\right)$ was selected as the principal parameter. Subsequently, a multiple regression, including, one by one, all the variables considered, was conducted. The criterion for accepting a new variable in the model was the increase of $R^{2}$ and the lowest correlation coefficient between variables (Canavos, 1988).

\section{Results and Discussion}

The Rg, VPD, and temperature for both crop cycles in the greenhouse are presented in Table 2. The different climatic parameter ranges are very narrow and they are included in the optimal ranges defined by different authors for this species: light intensity, from 8-22 $\mu \mathrm{mol} \cdot \mathrm{m}^{-2} \cdot \mathrm{s}^{-1}$ photons; high environmental relative humidity, $\approx 80 \%$; and mild temperatures, from $13{ }^{\circ} \mathrm{C}$ to $30{ }^{\circ} \mathrm{C}$ (Jiménez and Lao, 2001).

\section{Effect of nitrogen source on \\ phosphorus uptake.}

Phosphorus and $\mathrm{N}$ uptake display statistical differences $(P<0.05)$ depending on the $\mathrm{N}$ form applied (Table 3). Nitrogen uptake is $43 \%$ and $39 \%$ higher in $\mathrm{Tb}\left(50 \mathrm{NO}_{3}{ }^{-}: 50\right.$ $\left.\mathrm{NH}_{4}{ }^{+}\right)$and $\mathrm{Tc}\left(0: 100 \mathrm{NH}_{4}{ }^{+}-\mathrm{N}\right)$ respectively, compared with $\mathrm{Ta}\left(\mathrm{NO}_{3}{ }^{-}-\mathrm{N}\right)$; and $\mathrm{P}$ uptake is $27 \%$ and $18 \%$ higher in $\mathrm{Tb}\left(50 \mathrm{NO}_{3}{ }^{-}: 50\right.$ $\left.\mathrm{NH}_{4}{ }^{+}\right)$and $\mathrm{Tc}\left(0: 100 \mathrm{NH}_{4}{ }^{+}-\mathrm{N}\right)$ respectively, compared with $\mathrm{Ta}\left(\mathrm{NO}_{3}{ }^{-}-\mathrm{N}\right)$. This difference generates a significantly higher concentration in leaves between all treatments as well (Table 3). There are no significant differences between $\mathrm{Tb}$ and $\mathrm{Tc}$, but the average $\mathrm{P}$ uptake was higher in $\mathrm{Tb}$ (Table3). These results were consistent with those obtained by Lorenzo et al. (2000) and Subbaswamy et al. (2001) in rose and mulberry respectively, who found a higher phosphate uptake when the ammonium $\left(\mathrm{NH}_{4}{ }^{+}-\mathrm{N}\right)$ content increases. However, Elia et al. (1996) detected a decrease in the phosphate leaf content when the $\mathrm{NO}_{3}{ }^{-}$-to$\mathrm{NH}_{4}^{+}$ratio decreases in eggplants.

The higher $\mathrm{P}$ uptake observed in the $\mathrm{NH}_{4}{ }^{+}-\mathrm{N}$ treatments may be the result of a stimulation of the $\mathrm{H}_{2} \mathrm{PO}_{4}^{-}$uptake when the $\mathrm{NO}_{3}{ }^{-}$uptake is strongly depressed (Mengel and Kirkby, 2001).

Mengel and Kirkby (2001) observed that plants fed with the $\mathrm{NH}_{4}{ }^{+}-\mathrm{N}$ source contained higher concentrations of inorganic anions $\left(\mathrm{SO}_{4}{ }^{2-}, \mathrm{H}_{2} \mathrm{PO}_{4}^{-}, \mathrm{Cl}^{-}\right)$, whereas cations $\left(\mathrm{Ca}^{2+}\right.$, $\mathrm{Mg}^{2+}, \mathrm{K}^{+}$) were present in lower concentrations. In contrast, the plants supplied with the $\mathrm{NO}_{3}{ }^{-} \mathrm{N}$ form contained a higher cation content (Bar-Tal et al., 2001). However, Raghavendra (1980) reported that the K content of the epidermal tissues of Commelina benghalensis L. was higher when no inorganic anion

\begin{tabular}{|c|c|c|c|c|c|c|c|c|c|}
\hline Treatment & $\mathrm{pH}$ & $\begin{array}{c}\mathrm{EC} \\
\left(\mathrm{dS} \cdot \mathrm{m}^{-1}\right)\end{array}$ & $\begin{array}{c}\mathrm{NO}_{3}^{-} \\
\left(\mathrm{mmol} \cdot \mathrm{L}^{-1}\right)\end{array}$ & $\begin{array}{c}\mathrm{NH}_{4}^{+} \\
\left(\mathrm{mmol} \cdot \mathrm{L}^{-1}\right)\end{array}$ & $\begin{array}{c}\mathrm{H}_{2} \mathrm{PO}_{4}^{-} \\
\left(\mathrm{mmol} \cdot \mathrm{L}^{-1}\right)\end{array}$ & $\begin{array}{c}\mathrm{SO}_{4}{ }^{2-} \\
\left(\mathrm{mmol} \cdot \mathrm{L}^{-1}\right)\end{array}$ & $\begin{array}{c}\mathrm{K}^{+} \\
\left(\mathrm{mmol} \cdot \mathrm{L}^{-1}\right)\end{array}$ & $\begin{array}{c}\mathrm{Ca}^{2+} \\
\left(\mathrm{mmol} \cdot \mathrm{L}^{-1}\right)\end{array}$ & $\begin{array}{c}\mathrm{Mg}^{2+} \\
\left(\mathrm{mmol} \cdot \mathrm{L}^{-1}\right)\end{array}$ \\
\hline $\mathrm{Ta}\left(100 \mathrm{NO}_{3}^{-}: 0 \mathrm{NH}_{4}{ }^{+}\right)$ & 6.5 & 1.0 & 6.0 & 0.0 & 1.2 & 1.0 & 4.0 & 0.9 & 2.4 \\
\hline $\mathrm{Tb}\left(50 \mathrm{NO}_{3}^{-}: 50 \mathrm{NH}_{4}^{+}\right)$ & 6.5 & 1.4 & 3.0 & 3.0 & 1.2 & 4.0 & 4.0 & 0.9 & 2.4 \\
\hline $\mathrm{Tc}\left(0 \mathrm{NO}_{3}^{-}: 100 \mathrm{NH}_{4}^{+}\right)$ & 6.5 & 1.8 & 0.0 & 6.0 & 1.2 & 7.5 & 4.0 & 0.9 & 2.4 \\
\hline
\end{tabular}

Table 1. Concentrations, $\mathrm{pH}$, and electrical conductivity of the used nutrient solution.

EC, electrical conductivity. 
was applied than the content when chloride or nitrate $\left(\mathrm{NO}_{3}{ }^{-}-\mathrm{N}\right)$ were present in the fertigation solution. In this case, the $\mathrm{N}$ form had no effect on $\mathrm{K}$ uptake (Table 3 ).

The higher $\mathrm{P}$ uptake observed in the ammonium treatments can also be the result of $\mathrm{pH}$ differences in the recycled solution (Mengel and Kirkby, 2001; Yu et al., 2003), because of the great importance of the proton-anion cotransport through the apoplasm (Marschner, 1995). The use of $\mathrm{NH}_{4}{ }^{+}-\mathrm{N}$ in recycled solutions generates an important $\mathrm{pH}$ decrease because of the nitrification process (Jiménez and Lao, 2001) of the mentioned proton release via the $\mathrm{NH}_{4}{ }^{+}$-proton antiport (countertransport). In this trial (data presented in Jiménez and Lao, 2001), the initial $\mathrm{pH}$ was 6.5 for all treatments, and the final $\mathrm{pH}$ range was 4 to 5 for the $\mathrm{NH}_{4}{ }^{+}-\mathrm{N}$ treatments, whereas $\mathrm{pH}$ increased between 0.5 and 1 point in the $\mathrm{NO}_{3}{ }^{-}-\mathrm{N}$ treatment.

The N-to-P uptake ratio was 3.4, 4.4, and 5.0 for the treatments $\mathrm{Ta}, \mathrm{Tb}$, and $\mathrm{Tc}$ respectively. These values are similar to those reached by Economakis and Krulj (2002) for a strawberry crop.

These results showed a higher N-to-P uptake ratio in the $\mathrm{NH}_{4}{ }^{+}-\mathrm{N}$ treatments, which means that the $\mathrm{N}$ uptake was higher than the $\mathrm{P}$ uptake, but $\mathrm{P}$ and $\mathrm{N}$ uptakes were higher in $\mathrm{NH}_{4}{ }^{+}-\mathrm{N}$ treatments (Table 3 ). For this reason, the $\mathrm{N}$-to-P uptake ratio must be considered in the nutritive solution formulation and it depends on the $\mathrm{N}$ supply source.

A low fertilizer use efficiency can influence in a negative way both yield and crop quality (Carrasco, 2002). Nutrient use efficiency can be defined as the dry weight of the organic matter produced (in grams) divided by the nutrient uptake (in grams) (Phiri et al., 2003). Treatments Ta, Tb, and Tc present a $P$ use efficiency of 35,38 , and $43 \mathrm{~g} \cdot \mathrm{g}^{-1}$. In this way, the use of $\mathrm{NH}_{4}{ }^{+}-\mathrm{N}$ or a combination

Table 2. Average temperature, global radiation, and vapor pressure deficit in the greenhouse for both trials during the days after transplanting.

\begin{tabular}{|c|c|c|c|c|c|c|}
\hline \multirow[b]{2}{*}{ DAT } & \multicolumn{3}{|c|}{ First trial } & \multicolumn{3}{|c|}{ Second trial } \\
\hline & $\overline{\operatorname{Rg}\left(\mathrm{MJ} \cdot \mathrm{m}^{-2} \cdot \mathrm{d}^{-1}\right)}$ & VPD $(\mathrm{kPa})$ & $\mathrm{T}\left({ }^{\circ} \mathrm{C}\right)$ & $\overline{\mathrm{Rg}\left(\mathrm{MJ} \cdot \mathrm{m}^{-2} \cdot \mathrm{d}^{-1}\right)}$ & VPD $(\mathrm{kPa})$ & $\overline{\mathrm{T}}\left({ }^{\circ} \mathrm{C}\right)$ \\
\hline 40 & & & & 2.57 & -0.25 & 20.1 \\
\hline 60 & & & & 2.49 & -0.30 & 18.3 \\
\hline 80 & 2.21 & -0.74 & 22.6 & 2.41 & -0.30 & 18.5 \\
\hline 100 & 6.22 & -1.01 & 26.6 & 3.07 & -0.44 & 18.7 \\
\hline 120 & 5.96 & -0.88 & 26.1 & 3.78 & -0.55 & 20.8 \\
\hline 140 & 2.94 & -0.93 & 27.2 & 4.13 & -0.29 & 22.6 \\
\hline 160 & 3.73 & -0.35 & 31.2 & 5.52 & -0.51 & 24.9 \\
\hline 180 & 3.46 & -0.07 & 29.1 & 6.30 & -0.27 & 24.4 \\
\hline 200 & 3.36 & -0.13 & 30.3 & 1.92 & -0.30 & 24.1 \\
\hline 220 & & & & 2.24 & -0.57 & 25.1 \\
\hline 240 & & & & 2.49 & -0.54 & 27.2 \\
\hline
\end{tabular}

DAT, days after transplanting; Rg, global radiation; VPD, vapor pressure deficit; $\mathrm{T}$, temperature.
$\mathrm{NH}_{4}{ }^{+}-\mathrm{NO}_{3}{ }^{-}$in the nutrient solution improves $\mathrm{P}$ use efficiency.

\section{Empirical models of phosphorus uptake and phosphorus uptake concentration}

Phosphorus uptake. A simple regression between $\mathrm{P}$ uptake and climate and between $\mathrm{P}$ uptake and growth parameters was done to establish models that permit one to estimate $P$ uptake (Fig. 1). Attending to the previous results, $\mathrm{Tb}$ and $\mathrm{Tc}$ were studied together ture, LAI, and water uptake were the best correlated parameters with $\mathrm{P}$ uptake. However, these results did not express a good relation between nutrient uptake and $\operatorname{Rg}\left(R^{2}=\right.$ 0.12 and 0.15 for the $\mathrm{NO}_{3}{ }^{-} \mathrm{N}$ and $\mathrm{NH}_{4}{ }^{+}-\mathrm{N}$ treatments respectively) nor between nutrient uptake and VPD (Fig. 1; $R^{2}=0$ for all treatments). However, van Goor et al. (1988) found that a high light intensity is linked to a higher dry weight and to a higher nutrients requirement as well. In addition, a low light intensity leads to a diminution of the nutrient uptake (Kafkafi et al., 1984). Schüssler (1995) found that a high water VPD increases the transpiration from the plant and, therefore, nutrient uptake is also increased. There is no relation between these parameters, perhaps because $\mathrm{P}$ is less affected by the transpiration stream, because this element is taken up in an active way (Marschner, 1995).

The coefficient of regression between $\mathrm{P}$ uptake and temperature was $R^{2}=0.51$ and 0.57 for the $\mathrm{NO}_{3}{ }^{-}-\mathrm{N}(\mathrm{Ta})$ and $\mathrm{NH}_{4}{ }^{+}-\mathrm{N}(\mathrm{Tc})$ treatments respectively. The thermal inertia in container crops is lower than in soil crops, and the environment temperature is similar to the root temperature (García et al., 2002). Economakis and Krulj (2002) observed that there is an increment of the P uptake when the root temperature increases. Plant roots are considering the $\mathrm{NH}_{4}^{+}-\mathrm{N}$ applied. Tempera- able to absorb $\mathrm{P}$ from diluted dissolutions by an active uptake process, with an adenosine triphosphate consumption associated with the respiration process (Marschner, 1995). The respiration speed increases $\approx 2.2$ times per each $10{ }^{\circ} \mathrm{C}$, and it has been found that nutrient uptake is increased when temperature becomes bigger in the same proportion (Joiner et al., 1983). In addition, Raghothama and Karthikeyan (2005) consider that major biochemical processes such as photosynthesis and respiration are activated by inorganic phosphate or its organic derivatives.

The coefficient of regression between $\mathrm{P}$ uptake and LAI was 0.70 and 0.67 for $\mathrm{NO}_{3}{ }^{-} \mathrm{N}$ (Ta) and $\mathrm{NH}_{4}{ }^{+}-\mathrm{N}$ (Tc) treatments respectively. Leaf area index quantifies directly the plant canopy structure, so it is highly related to a variety of canopy processes, such as photosynthesis and respiration, and it is also associated with dry weight production (Penning de Vries, 1974), temperature, and nutrient supply (Lawlor, 1991). Economakis and Krulj (2002) reported a correlation between nutrient uptake and growth rate.

To improve the model, a multivariable regression between $\mathrm{P}$ uptake and the tested parameters (Table 4), taking LAI as the fixed variable, because it had the higher determination coefficient, was undertaken. There were no multiple regressions that could improve the model of $\mathrm{P}$ uptake in the $\mathrm{NO}_{3}{ }^{-}$$\mathrm{N}$ treatment. However, a multiple regression with LAI and radiation explains better the $\mathrm{P}$ uptake in the $\mathrm{NH}_{4}{ }^{+}-\mathrm{N}$ treatment.

Phosphorus uptake concentration. A regression between $\mathrm{P}$ uptake and water uptake was done to estimate the $\mathrm{P}$ uptake concentration (P-to-water uptake ratio) for the two trials (Fig. 1). The linear regression equations presented and $R^{2}$ value of 0.58 and 0.64 , and slopes of 2.04 and of $2.61 \mathrm{mmol} \cdot \mathrm{L}^{-1}$ for the treatments with $\mathrm{NO}_{3}^{-}-\mathrm{N}(\mathrm{Ta})$ and $\mathrm{NH}_{4}{ }^{+}-\mathrm{N}(\mathrm{Tc})$ respectively. These values are similar to the ones cited by Magán (1999) in tomato crops and are a little bit smaller than those obtained by Sheen and Hsu (1996) in melon crops. This uptake concentration indicates that $\mathrm{P}$ and water uptake depend on the $\mathrm{N}$ form applied, and that $\mathrm{P}$ and water are taken up in different amounts. These results agree with those obtained by Rouphael et al. (2004), who observed that the recycled solution showed $40 \%$ depletion after $73 \mathrm{~d}$. The nutrient solution concentration in the growth medium is modified when nutrient solutions with a constant salt concentration are added to a hydroponic system, with these variations incited by changes in the nutrient-to-water uptake ratio. Nevertheless, it is difficult to

Table 3. Leaf area index, nitrogen $\left(\mathrm{NO}_{3}{ }^{-}-\mathrm{N}+\mathrm{NH}_{4}{ }^{+}-\mathrm{N}\right)$, potassium, and phosphorus uptake and shoot phosphorus concentration as affected by the ratio of $\mathrm{NO}_{3}{ }^{-}-\mathrm{N}$ and $\mathrm{NH}_{4}{ }^{+}-\mathrm{N}$ in the supplied nutrient solution.

\begin{tabular}{|c|c|c|c|c|c|c|}
\hline Treatments & $\begin{array}{l}\text { LAI, first trial } \\
\left(\mathrm{m}^{2} \cdot \mathrm{m}^{-2}\right)\end{array}$ & $\begin{array}{l}\text { LAI, second trial, } \\
\left(\mathrm{m}^{2} \cdot \mathrm{m}^{-2}\right)\end{array}$ & $\begin{array}{c}\mathrm{N} \text { uptake } \\
\left(\mathrm{mmol} \cdot \mathrm{d}^{-1} / \text { plant }\right)\end{array}$ & $\begin{array}{c}\text { P uptake } \\
\left(\mathrm{mmol} \cdot \mathrm{d}^{-1} / \text { plant }\right)\end{array}$ & $\begin{array}{c}\text { K uptake } \\
\left(\mathrm{mmol} \cdot \mathrm{d}^{-1} / \text { plant }\right)\end{array}$ & $\begin{array}{c}\text { Shoot P concn. } \\
\left(\mathrm{mg} \cdot \mathrm{g}^{-1}\right)\end{array}$ \\
\hline $\mathrm{Ta}\left(100 \mathrm{NO}_{3}^{-}: 0 \mathrm{H}_{4}^{+}\right)$ & $1.62 \pm 0.30 \mathrm{~b}$ & $1.47 \pm 0.20 \mathrm{~b}$ & $0.82 \pm 0.16 \mathrm{~b}$ & $0.24 \pm 0.09 \mathrm{~b}$ & $0.55 \pm 0.20 \mathrm{a}$ & $3.6 \pm 0.1 \mathrm{c}$ \\
\hline $\mathrm{Tb}\left(50 \mathrm{NO}_{3}^{-}: 50 \mathrm{H}_{4}^{+}\right)$ & $2.02 \pm 0.20 \mathrm{a}$ & $2.34 \pm 0.23 \mathrm{a}$ & $1.45 \pm 0.20 \mathrm{a}$ & $0.33 \pm 0.14 \mathrm{a}$ & $0.71 \pm 0.20 \mathrm{a}$ & $3.9 \pm 0.1 b$ \\
\hline $\mathrm{Tc}\left(0 \mathrm{NO}_{3}^{-}: 100 \mathrm{H}_{4}^{+}\right)$ & $1.95 \pm 0.21 \mathrm{ab}$ & $1.51 \pm 0.25 \mathrm{ab}$ & $1.35 \pm 0.15 \mathrm{a}$ & $0.27 \pm 0.09 \mathrm{a}$ & $0.51 \pm 0.19 \mathrm{a}$ & $4.4 \pm 0.2 \mathrm{a}$ \\
\hline
\end{tabular}

Mean separation in rows by LSD $(P<0.05)$

LAI, leaf area index. 

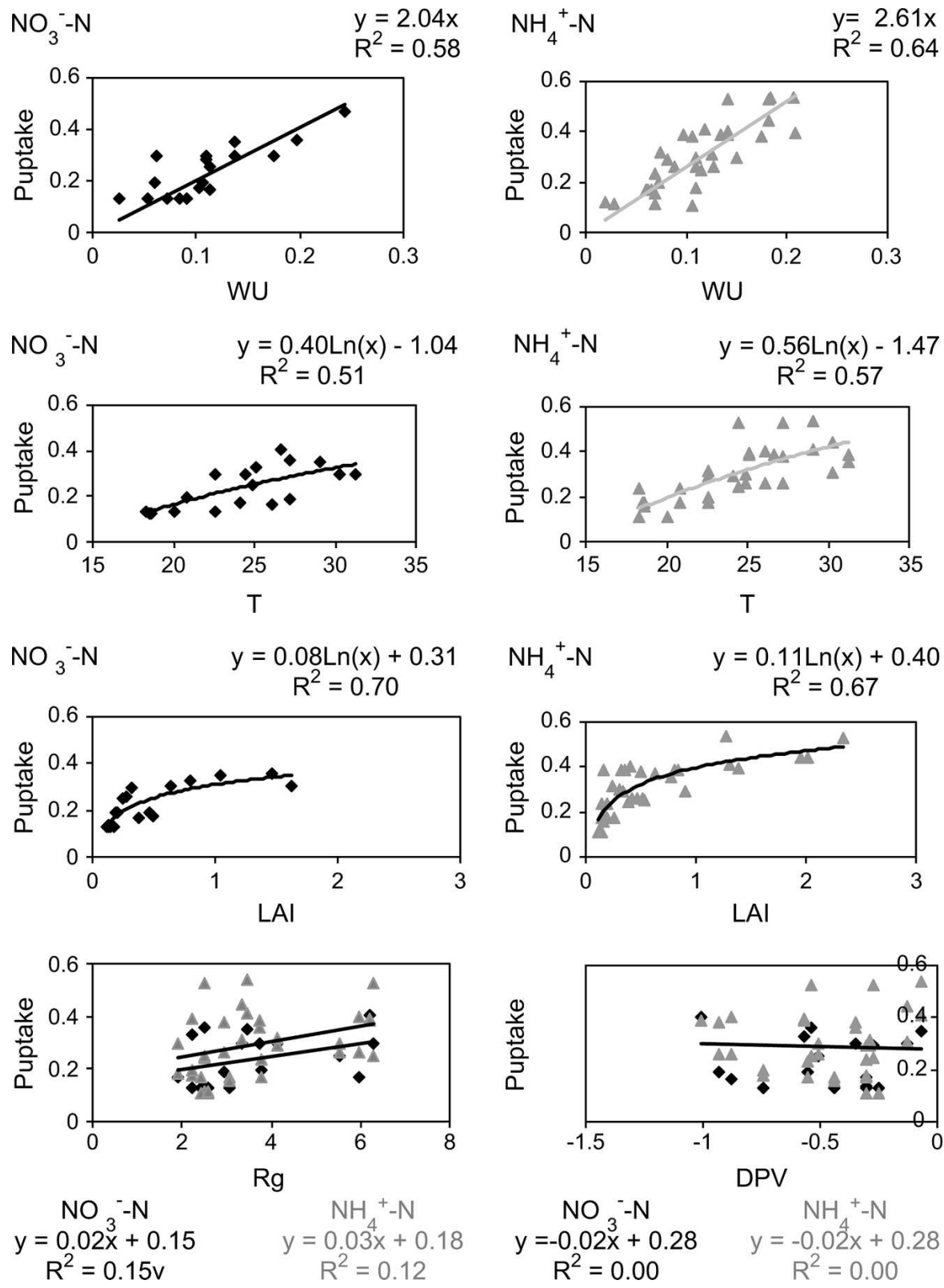

$$
\begin{gathered}
\mathrm{NO}{ }^{-}-\mathrm{N} \\
y=-0.02 x+0.28 \\
R^{2}=0.00
\end{gathered}
$$

$$
\begin{gathered}
\mathrm{NH}_{4}{ }^{+}{ }^{-} \mathrm{N} \\
-0.02 x+0.28 \\
R^{2}=0.00
\end{gathered}
$$

Fig. 1. Simple regression between the phosphorus $(\mathrm{P})$ uptake $\left(\mathrm{mmol} \cdot \mathrm{d}^{-1} / \mathrm{plant}\right)$ and water uptake $(\mathrm{WU}$; in liters per day per plant), temperature (T; in degrees Celsius), leaf area index (LAI; in square meters per square meter), global radiation ( $\mathrm{Rg}$, in megajoules per square meter per day), and vapor pressure deficit (VPD; in kilo-Pascals). Significance of the correlation, $P<0.05$.

Table 4. Multiple regressions between phosphorus uptake and climatic and growth parameter.

\begin{tabular}{llcc}
\hline Treatment & P uptake model & $R^{2}$ & $\begin{array}{c}\text { Covariance between } \\
\text { independent variables }\end{array}$ \\
\hline Treatment A & f(LnLAI.T) & 0.84 & -0.81 \\
& f(LnLAI.Wup) & 0.81 & -0.86 \\
Treatments B and C & f(LnLAI.VPD) & 0.58 & -0.21 \\
& f(LnLAI.Rg) & 0.58 & 0.08 \\
& f(LnLAI.T) & 0.69 & -0.81 \\
& f(LnLAI.Wup) & 0.67 & -0.86 \\
& f(LnLAI.VPD) & 0.68 & -0.16 \\
\hline
\end{tabular}

Coefficients are significant at $0.5 \%$ level.

maintain nutrient equilibrium, because plant uptake can be dissimilar for different crops (Ehret et al., 2005). In order to maintain an invariable $\mathrm{P}$ concentration in the nutritive solution, the amount of $\mathrm{P}$ applied should be equal to the $\mathrm{P}$ uptake concentration, but this relation is not constant because it varies depending on the environmental conditions (Kläring et al., 1997) and the plant age. In this assay, the $R^{2}$ value of the simple regression between uptake concentration and temperature, Rg, VPD and LAI was less than 0.1, so a regression could not explain the cited concentration variations. However, Kläring et al. (1997) showed that P uptake concentration was strongly affected by temperature, with an $R^{2}$ value of 0.67 , but was less influenced by $\mathrm{Rg}$.

\section{Comparison between models to estimate} phosphorus uptake concentration

This work proposes two models to estimate the P uptake concentration: 1) a fixed concentration value obtained by the slope of the linear correlation between $\mathrm{P}$ uptake and water uptake, and 2) a relation between the estimated $\mathrm{P}$ uptake through the model and the experimental water uptake. The $1 \%$ error and the $\mathrm{SE}$ deviation for the nitrate $\left(\mathrm{NO}_{3}{ }^{-} \mathrm{N}\right)$ treatment were $0.17,0.28$ and $0.12,0.16$ and, for the ammonium $\left(\mathrm{NH}_{4}{ }^{+}-\mathrm{N}\right)$ treatments, were $0.29,0.28$ and $0.12,0.2$ for the fixed value and the model respectively. The use of a unique $P$ uptake concentration offers low precision and, on other hand, the second model is more closely related to the experimental values.

\section{Conclusion}

The $\mathrm{N}$ form applied to $D$. amoena plants affects $\mathrm{P}$ and $\mathrm{N}$ uptake, but it does not influence $\mathrm{K}$ uptake. Nitrogen and P uptake rates are higher in the plants supplied with $\mathrm{NH}_{4}{ }^{+}$or $\mathrm{NO}_{3}{ }^{-}+\mathrm{NH}_{4}{ }^{+}$than in plants provided with $\mathrm{NO}_{3}{ }^{-}$alone. The supply of a combination $50 \mathrm{NO}_{3}^{-}$: $50 \mathrm{NH}_{4}^{+}$improves $\mathrm{P}$ use efficiency. The study also indicates the possibility of predicting the $\mathrm{P}$ uptake rate and $\mathrm{P}$ uptake concentration using the proposed models. Phosphorus uptake can be estimated with a model dependent on the LAI in the $\mathrm{NO}_{3}{ }^{-}-\mathrm{N}$ treatments, and on the $\mathrm{LAI}$ and $\mathrm{Rg}$ in the $\mathrm{NH}_{4}{ }^{+} \mathrm{N}$ treatments. The $\mathrm{P}$ uptake concentration can be calculated with the $\mathrm{P}$ uptake, estimated through the previous model, and the experimental water uptake. This parameter would permit a nutritive solutions design, diminishing the nutrient losses in open systems.

\section{Literature Cited}

Abbès, C., L.E. Parent, A. Karam, and D. Isfan. 1995. Effect of $\mathrm{NH}_{4}+: \mathrm{NO}_{3}-$ ratios on growth and nitrogen uptake by onions. Plant Soil 171:289-296.

Bar-Tal, A., B. Alón, L. Karni, and R. Rosenberg. 2001. Nitrogen nutrition of greenhouse pepper. II Effects of nitrogen concentration and $\mathrm{NO}_{3}: \mathrm{NH}_{4}$ ratio on growth, transpiration and nutrient uptake. HortScience 36:1252-1259.

Battilani, A. 2003. DY-FERT HC: A low-input dynamic approach to managing fertigation on a daily basis. Acta Hort. 613:159-162.

Brun, R. and L. Chazelle. 1996. Water and nitrate absorption kinetics in the nychthemeral cycle of rose grown in the greenhouse using a recirculating solution. J. Plant Nutr. 19:839867.

Canavos, G.C. 1988. Probabilidad y Estadística. Aplicaciones y Métodos. McGraw Hill, Madrid. 
Carrasco, I. 2002. Nuevas tecnologías en fertilización para el respeto del medio ambiente. Phytoma 135:23-28.

Economakis, C.D. and L. Krulj. 2002. Water and nutrient uptake by strawberry plants grown with the nutrient film technique (NFT) under different minimum solution temperatures. Acta Hort. 579:405-410.

Ehret, D., J. Menzies, and T. Helmer. 2005. Production and quality of greenhouse roses in recirculating nutrient systems. Sci. Hort. 106:103-113.

Elia, A., G. Conversa, F. Serio, and P. Santamaría. 1996. Response of eggplant to NH4:NO3 ratio. Intl. Soc. for Soilless Cult. 167-179.

García, J., M.T. Lao, S. Jiménez, and L.A. Chaves. 2002. Ensayo de calentamiento de la zona radical mediante el empleo de manta eléctrica. Plantflor 92:83-87.

Hamlin, R.L. and H.A. Mills. 2001. Pansy floral development and nutrient absorption as influenced by temperature, nitrogen form, and stage of plant development. J. Plant Nutr. 24:19751985.

Jiménez, S., J.I. Alés, M.T. Lao, B.M. Plaza, and M. Pérez. 2006. Evaluation of N concentration quick test for field determinations in a soil solution, drainage solution, and nutrient solution in fertigation. Commun. Soil Sci. Plant Anal. 37:2461-2469.

Jiménez, S., and M.T. Lao. 2001. Estudio de la evolución del $\mathrm{pH}$ y de la concentración de nitratos y amonio de la solución recirculante en cultivo de Dieffenbachia amoena 'Tropic Snow', p. 343-359 In: P. Cerdeño et al. (eds.). I Jornadas Ibéricas de plantas ornamentales. Conserjeria de Agricultura y Pesca de la Junta de Andalucía, Seville, Spain.

Jiménez, S. and M.T. Lao. 2005. Influence of nitrogen form on the quality of Dieffenbachia amoena 'Tropic Snow'. HortScience 40:386390.

Joiner, J.N., R.T. Poole, and C.A. Canover. 1983. Nutrition and fertilization of ornamental greenhouse crops, p. 319-399. In: J. Janick (eds.). Horticultural reviews. Hort. Nutr. AVI Publishing, Westport, Conn.

Kafkafi, U., E. Dayan, and B. Akiri. 1984. Nitrate and phosphate uptake by tomato from nutrient solution in a commercial operation. Intl. Soc. for Soilless Cult. 291-299.

Kelly, J.M. and J.K. Kelly. 2001. Phosphorus and potassium uptake kinetics in red maple seedlings. For. Sci. 47:397-402.

Kläring, H.P., D. Schwarz, and A. Heissner. 1997. Control of nutrient solution concentration in tomato crop using models of photosynthesis and transpiration: A simulation study. Acta Hort. 450:329-334.

Lao, M.T., S. Jiménez, E.J. Fernández, and F. Camacho. 2003. Buried solar greenhouse (Insole): Description, equipment, climatic behaviour under Mediterranean conditions and their applications in ornamental crops. Acta Hort. 614:427-433.

Lawlor, D.W. 1991. Concepts of nutrition in relation to cellular processes and environment, p. 1-32. In: J.R. Porter and D.W. Lawlor (eds.). Plant growth interactions with nutrition and environment. Cambridge University Press, Cambridge, UK.

Le Bot, J., S. Adamowicz, and P. Robin. 1998. Modelling plant nutrition of horticultural crops: A review. Sci. Hort. 74:47-82.

Lewis, D.R. and M.B. McGechan. 2002. A review of field scale phosphorus dynamics models. Biosystems Eng. 82:359-380.

Lorenzo, H., M.C. Cid, J.M. Siverio, and M. Caballero. 2000. Influence of additional ammonium supply on some nutritional aspects in hydroponics rose plants. J. Agr. Sci. 134:421425.

Magán, J.J. 1999. Sistemas de cultivo en sustrato: A solución perdida y con recirculación del lixiviado, p. 173-205 In: M. Fernández, I.M. Cuadrado (eds.). Cultivos sin suelo II. Dirección general de investigaciones y formación agriaría, F.I.A.P.A., Caja rural de Almería. Press, Almería, Spain.

Marschner, H. 1995. Mineral nutrition of higher plants. 2nd ed. Academic, London.

Mengel, K. and E.A. Kirkby. 2001. Principles of plant nutrition. 5th ed. Intl. Potash Inst, Switzerland.

Ministry of Agriculture and Fishing. 1994. Métodos Oficiales de Análisis. Tomo III. Secretaría General Técnica, Madrid.

Papadopoulos, A.P. and N. Liburdi. 1989. The Harrow fertigation manager: A computerized injector. Acta Hort. 260:255-265.

Pardossi, A., F. Falossi, F. Malorgio, L. Incrocci, and G. Bellocchi. 2004. Empirical models of macronutrient uptake in melon plants grown in recirculating nutrient solution culture. J. Plant Nutr. 27:1261-1280.

Penning de Vries, F.W.T. 1974. Substrate utilization and respiration in relation to growth and maintenance in higher plants. Netherlands J. Agr. Sci. 22:40-44.

Phiri, S., I.M. Rao, E. Barrios, and B.R. Singh. 2003. Plant growth, mycorrhizal association, nutrient uptake and phosphorus dynamics in a volcanic-ash soil in Colombia as affected by the establishment of Tithonia diversifolia. J. Sust. Agr. 21:43-61.

Raghavendra, A.S. 1980. Chloride and nitrate stimulate stomatal opening and decrease potassium uptake and malate production in epidermal tissues of Commelina benghalensis. Aust. J. Plant Physiol. 7:663-669.

Raghothama, K.G. and A.S. Karthikeyan. 2005. Phosphate acquisition. Plant Soil 274:3749.

Rosenberg, N.J., L.B. Blaine, and S.B. Verma. 1983. Microclimate. The biological environment. Wiley-Interscience, New York.

Rouphael, Y., G. Colla, A. Battistelli, S. Moscatello, S. Proietti, and E. Rea. 2004. Yield, water requirement, nutrient uptake and fruit quality of zucchini squash grown in soil and closed soilless culture. J. Hort. Sci. Biotechnol. 79:423-430.

Schüssler, H.K. 1995. Effect of various water vapor pressure deficit gradients and nitrogen levels on morphogenesis of Euphorbia Pulcherrima "freedom". Acta Hort. 378:310-315.

Sheen, T.F. and M.M. Hsu. 1996. Studies on nutrient uptake by greenhouse muskmelon (cucumis melo L.) in hydroponics. Intl. Soc. for Soilless Cult. 491-503.

Subbaswamy, M.R., N.R. Singhvi, B.V. Naidu, M.M. Reddy, H. Jayaram, and N. Suryanarayan. 2001. Effect of source of nitrogen on phosphorus uptake and arginine content in mulberry. Ind. J. Sericulture. 40:182184.

Thomson, C.J., H. Marschner, and V. Römheld. 1993. Effect of nitrogen fertilizer form on $\mathrm{pH}$ of the bulk soil and rhizosphere, and on the growth, phosphorus, and micronutrient uptake of bean. J. Plant Nutr. 16:493-506.

van Goor, B.J., A. de Jager, and W. Voogt. 1988. Nutrient uptake by some horticultural crops during the growing period. Intl. Soc. for Soilless Cult. 163-177.

Yan, X., H. Liao, A. Cao, and Y. He. 2001. The role of root architecture in $\mathrm{P}$ acquisition efficiency of different root systems: A case study with common bean and rice, p. 590-591 In: W.J. Horst et al. (eds.). Plant nutrition: Food security and sustainability of agro ecosystems through basic and applied research. Kluwer Academic Publishers, the Netherlands.

Yu, S.J., J.S. Lee, S.J. Jeong, and B.S. Yoo. 2003. Nutrient uptake patterns of native rhododendron species in Korea and China under ebb and flow subirrigation. J. Korean Soc. Hort. Sci. 44:824-828. 